\title{
MESOCOSM EXPERIMENTS TO ASSESS FACTORS AFFECTING PHOSPHORUS RETENTION AND RELEASE IN AN EXTENDED WISCONSIN WETLAND
}

\section{By John F. Elder, Bart J. Manion, and Gerald L. Goddard}

U.S. GEOLOGICAL SURVEY

Water-Resources Investigations Report 97-4272

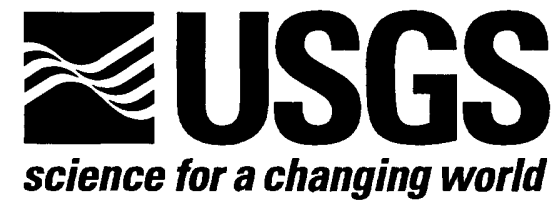

Prepared in cooperation with the WISCONSIN DEPARTMENT OF NATURAL RESOURCES

\author{
Middleton, Wisconsin \\ 1997
}

Cover photo: A mesocosm in Jackson Creek Wetland, southeastern Wisconsin, for experiments to determine factors affecting phosphorus retention. Photo shows silicone tubing connected to an exterior pump, providing controlled circulation through each of the four mesocosm cells. Also pictured is the equipment used for periodic monitoring of water-quality parameters in the mesocosm. 


\title{
U.S. DEPARTMENT OF THE INTERIOR BRUCE BABBITT, Secretary
}

\author{
U.S. GEOLOGICAL SURVEY \\ Mark Schaefer, Acting Director
}

District Chief

U.S. Geological Survey

8505 Research Way

Middleton, WI 53562
U.S. Geological Survey

Branch of Information Services

Box 25286

Denver, CO 80225-0286 


\section{PREFACE}

This Water-Resources Investigation Report is the latest of a series of reports that address dynamics of phosphorus transport through the stream and wetland system that constitutes the primary surface-water inflow to Delavan Lake, southeastern Wisconsin. Since 1992, the U.S. Geological Survey studies in this area have included monitoring at fixed sites to characterize inflows and outflows of different components of the system, as well as experimental work to examine processes that are involved in phosphorus retention and transport. This report presents results from an experimental study (mesocosm experiments) and compares them with field data. An overview of some of the monitoring results and mass balance calculations is included herein; however, further details of the field monitoring work are available in earlier reports (Elder and Goddard, 1996; Goddard and Elder, 1997; and Robertson and others, 1996), which are cited at the end of this report. 


\section{CONTENTS}

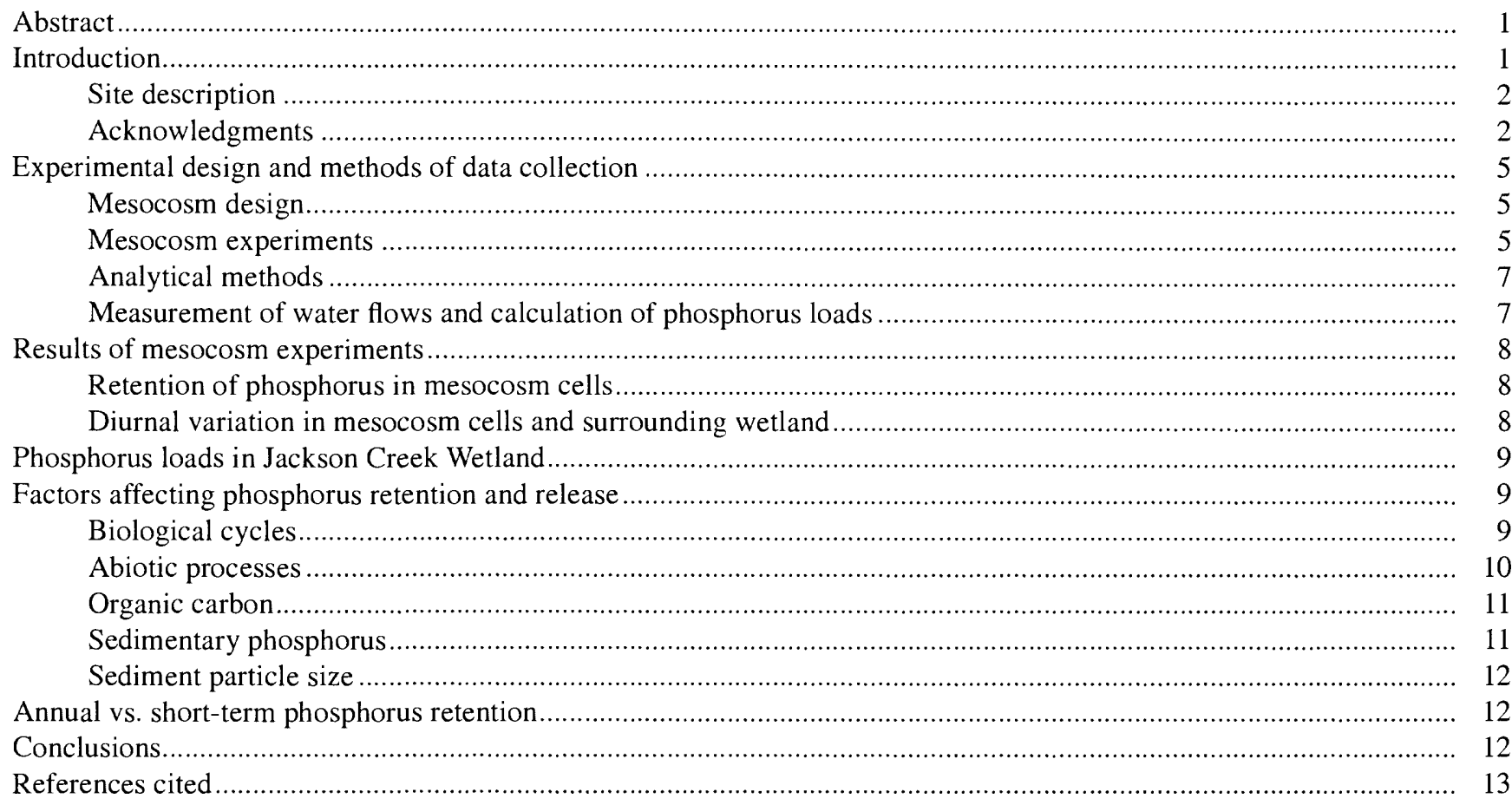

\section{FIGURES}

1. Map showing location of Delavan Lake, Jackson Creek Wetland, three inflowing streams (Jackson Creek and its tributaries), and outflow of wetlands to Delavan Lake inlet

2. Aerial view of Jackson Creek Wetland, showing inflowing and outflowing streams and location of mesocosm.

3. Mesocosm in place in Jackson Creek Wetland

4. Comparison of total phosphorus concentrations in control cells vs. cells containing sediments and water, experiments 1 and 2

5. Total and soluble phosphorus in outflows from four mesocosm cells, experiment 3

\section{TABLES}

1. Composite daily means (medians of $\mathrm{pH}$ ) and ranges of water properties in mesocosm cells and in Jackson Creek Wetland

2. Aqueous total phosphorus concentrations in mesocosm cells (excluding day 0 ) and initial concentrations of organic carbon, total phosphorus, and $\mathrm{NaOH}$-extractable phosphorus in sediments of corresponding cells.

3. Inflow and outflow phosphorus loads for Jackson Creek Wetland, February 1993-September 1995 ................... 10 


\title{
CONVERSION FACTORS AND ABBREVIATED WATER-QUALITY UNITS
}

\begin{tabular}{rll}
\hline Multiply & By & To obtain \\
\hline millimeter $(\mathrm{mm})$ & & inch \\
centimeter $(\mathrm{cm})$ & 0.03937 & inch \\
meter $(\mathrm{m})$ & .3937 & foot \\
kilometer $(\mathrm{km})$ & 3.281 & mile \\
foot per mile \\
meter per kilometer $\left(\mathrm{m} / \mathrm{km}^{2}\right.$ & .6214 & square inch \\
square centimeter $\left(\mathrm{cm}^{2}\right)$ & 5.280 & square foot \\
square meter $\left(\mathrm{m}^{2}\right)$ & .1550 & acre \\
hectare & .0929 & square mile \\
square kilometer $\left(\mathrm{km}{ }^{2}\right)$ & 2.471 & inches per hour \\
feet per second \\
meter per second $\left(\mathrm{m}^{2} / \mathrm{s}\right)$ & .3861 & cubic foot per second \\
cubic meter per second $\left(\mathrm{m}^{3} / \mathrm{s}\right)$ & .3937 & cubic foot/hour/square yard \\
liter per hour per square meter $\left(\mathrm{L} / \mathrm{hr} / \mathrm{m}^{2}\right)$ & 3.281 & cubic foot
\end{tabular}

Temperature in degrees Celsius $\left({ }^{\circ} \mathrm{C}\right)$ can be converted to degrees Fahrenheit $\left({ }^{\circ} \mathrm{F}\right)$ by use of the following equation: ${ }^{\circ} \mathrm{F}=1.8\left({ }^{\circ} \mathrm{C}\right)+32$.

\begin{abstract}
Abbreviated water-quality units: Chemical concentration given in milligrams per liter (mg/L) or micrograms per liter ( $\mu \mathrm{g} / \mathrm{L})$. Milligrams per liter is a unit expressing the concentration of chemical constituents in solution as weight (milligrams) of solute per unit volume (liter) of water. Specific conductance of water is expressed in microsiemens per centimeter at 25 degrees Celsius ( $\mu \mathrm{S} / \mathrm{cm}$ ). This unit is equivalent to micromhos per centimeter at 25 degrees Celsius $(\mu \mathrm{mho} / \mathrm{cm})$, formerly used by the U.S. Geological Survey. The abbreviation "pH" represents the negative base 10 logarithm of hydrogen ion activity in moles per liter.
\end{abstract}




\title{
Mesocosm Experiments to Assess Factors Affecting Phosphorus Retention and Release in an Extended Wisconsin Wetland
}

\author{
By John F. Elder, Bart J. Manion, and Gerald L. Goddard
}

\section{Abstract}

Phosphorus retention by wetland sediments and vegetation was investigated in Jackson Creek wetland, an extension of an existing prairie marsh in southeastern Wisconsin. The extended wetland construction was undertaken in 1992-93 to help reduce the phosphorus loading to a downstream eutrophic lake. Two approaches were used to study potential and actual phosphorus retention in the system. Mesocosm experiments of 20-40 days duration indicated that retention of total and dissolved reactive phosphorus in mesocosm cells containing macrophytes and/or sediments was reduced by factors of 2-20 relative to cells containing only water or a copper algicide to suppress metabolic activity. In contrast to the nutrient trapping function, these results show a potential for net phosphorus release that can be associated with increased biological richness. Measurements of water flow and nutrient loads at the wetland's inflow and outflow points demonstrated $9-39 \%$ net uptake of phosphorus on an annual scale but frequent occurrences of net phosphorus release over shorter (one-month) time scales. These episodes of release are most likely during the summer months. Thus, the wetland role in phosphorus cycling is not one of a true source or sink, although the annual budget data alone suggest substantial net retention. Effective management of the wetland for its nutrient trapping potential can be hindered by this oversimplification. The system is instead subject to relatively short-term alternation between net import and export. The periodic phosphorus export, although representing a small fraction of net annual import, could be critical for growth of macrophyte and algal communities downstream.

\section{INTRODUCTION}

One of the commonly known values of wetlands is their capacity to function as sinks or traps for nutrients (Boyt and others, 1977; Brown, 1985; Puckett and others, 1993; National Research Council, 1995). This function can be particularly valuable for wetlands located within drainage areas of lakes that are subject to eutrophication due to excessive nutrient inflow, and it has led to numerous wetland construction projects primarily for the purpose of water-quality improvement (Hammer and Bastian, 1989; Moshiri, 1993; Kadlec and Knight, 1996).

In contrast to their nutrient-trap function, wetlands can also periodically release nutrients, and under certain conditions, retention can be exceeded by nutrient release (Richardson, 1985, 1988; Gehrels and Mulamoottil, 1989; Van der Linden, 1989). Information from studies of a variety of wetland systems clearly indicates that wetlands have diverse effects on constituent transport, depending on hydrologic, chemical, and biological properties and the successional stage of the system. If a wetland is constructed and expected to function as a water-purification system, effective management for this purpose can be facilitated by awareness of the complexity and natural variability of the system.

Because of its critical role in limitation of algal growth in lakes, phosphorus is often the primary target element of nutrient removal systems. Phosphorus sequestration in wetlands is dependent on processes associated with the sediments and biota of the system Such processes include: (1) uptake by rooted vegetation (Brinson and others, 1984) or microorganisms in the sediments (Richardson and Marshall, 1986; Kadlec, 1989), and (2) adsorption and precipitation reactions with ferric iron, calcium, aluminum, sediment particles, and organic particles (Nichols, 1983; 
Watson and others, 1989; Cooke and others, 1992; Gale and others, 1994).

To quantify the magnitude of phosphorus loading to Delavan Lake from its watershed, the U.S. Geological Survey (USGS), in cooperation with the Town of Delavan and the Wisconsin Department of Natural Resources (WDNR), has conducted a series of investigations of phosphorus transport in various components of the Jackson Creek stream system. The purpose of this study was to assess potential phosphorus transport and retention processes in a constructed wetland within the drainage basin of a eutrophic lake in southeastern Wisconsin. The hypothesis, consistent with the concept of nutrient retention, was that as water flows through the wetland, a certain fraction of its phosphorus load is retained or trapped in the system, and the amount of such retention increases with the time of contact with sediments and vegetation. This study tested that hypothesis, based on two different kinds of data: (1) from a series of experiments in a model system (mesocosm), and (2) from measurements of phosphorus inputs and outputs for the entire wetland system.

This report presents results from experiments using mesocosms (small enclosures representing the larger wetland), with respect to factors that affect phosphorus transport and retention. These results are compared with data from earlier and concurrent investigations of phosphorus inflows and outflows of the entire Jackson Creek wetland system. Overall interpretations about the processes involved in phosphorus transport, and the implications for wetland management are discussed.

\section{Site Description}

Delavan Lake is a major recreational lake and sport fishery in southeastern Wisconsin. Its primary surface-water inflow is from Jackson Creek and its two tributaries (Jackson Creek Tributary and Jackson Creek Tributary 2); these channels converge just upstream of their combined outflow to the lake (fig. 1). With a combined mean discharge of $0.34 \mathrm{~m}^{3} / \mathrm{s}$, Jackson Creek and its tributaries are the major transport channels for external-source sediment and nutrient loadings to the lake. In 1984-85, 95 percent of suspended sediment, 75 percent of phosphorus, 62 percent of Kjeldahl nitrogen, and 58 percent of nitrate nitrogen entered the lake through the Delavan Lake inlet (Field and Duerk, 1988).
Excessive algal growth, including nuisance blooms of blue-green algae, have plagued Delavan Lake in the past. The eutrophic condition of the lake has been attributed to periodically heavy phosphorus loading from both internal (within-lake) and external sources (Field and Duerk, 1988). Successful management of the lake to improve water quality thus depends in part on reduction of its tributary loading. With this goal in mind, a lake rehabilitation program (Wisconsin Department of Natural Resources, 1989), designed in the mid-1980's and implemented since then, included expansion of a prairie marsh just upstream of Delavan Lake inlet, at the confluence of the three Jackson Creek branches (figs. 1 and 2). The primary purpose of this wetland construction was to serve as a trap for nutrients and suspended sediments transported to the lake by the stream system.

Constructed in 1992, the 38-ha Jackson Creek wetland is more than 6 times greater in area than the natural prairie marsh that it replaced. Its catchment area is $43 \mathrm{~km}^{2}$, or 43 percent of the total drainage area of Delavan Lake. Eighty-nine percent of the land use in this catchment is agricultural (row crops, grain crops, and hay). Silty and poorly drained soils predominate in the gently rolling terrain.

The expanded wetland includes three sedimentation basins totaling 3.6 hectares. Swales extending from the sedimentation basins are designed to distribute water throughout the wetland, thereby inhibiting channelization and increasing the likelihood of nutrient and sediment retention in the system. In 1993, the plant community in the Jackson Creek wetland was a mixture of shallow-marsh and sedge-meadow species, dominated by sedges, grasses, bulrushes, anemone, angelica, and equisetum.

\section{Acknowledgments}

Analyses of phosphorus in water and sediments for this study were done at the Wisconsin State Laboratory of Hygiene. TOC and particle-size analyses of the sediments were done at the USGS Central Laboratory in Arvada, CO, and the Iowa District Sediment Laboratory, respectively. We thank J.W. Nunes for assistance with field work; G. Moede and M. Greenwood for assistance with preparation of manuscript and illustrations; and S.J. Field (USGS), C.M. Eberle (USGS), and G.T. Bowman (Wisconsin State Laboratory of Hygiene) for manuscript review. 

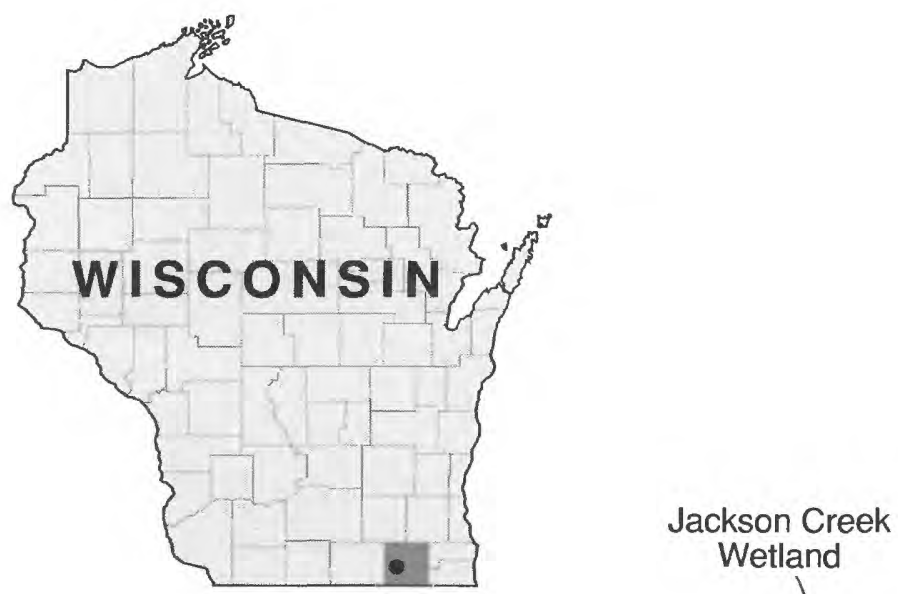

Wetland

Location of study area in Walworth County

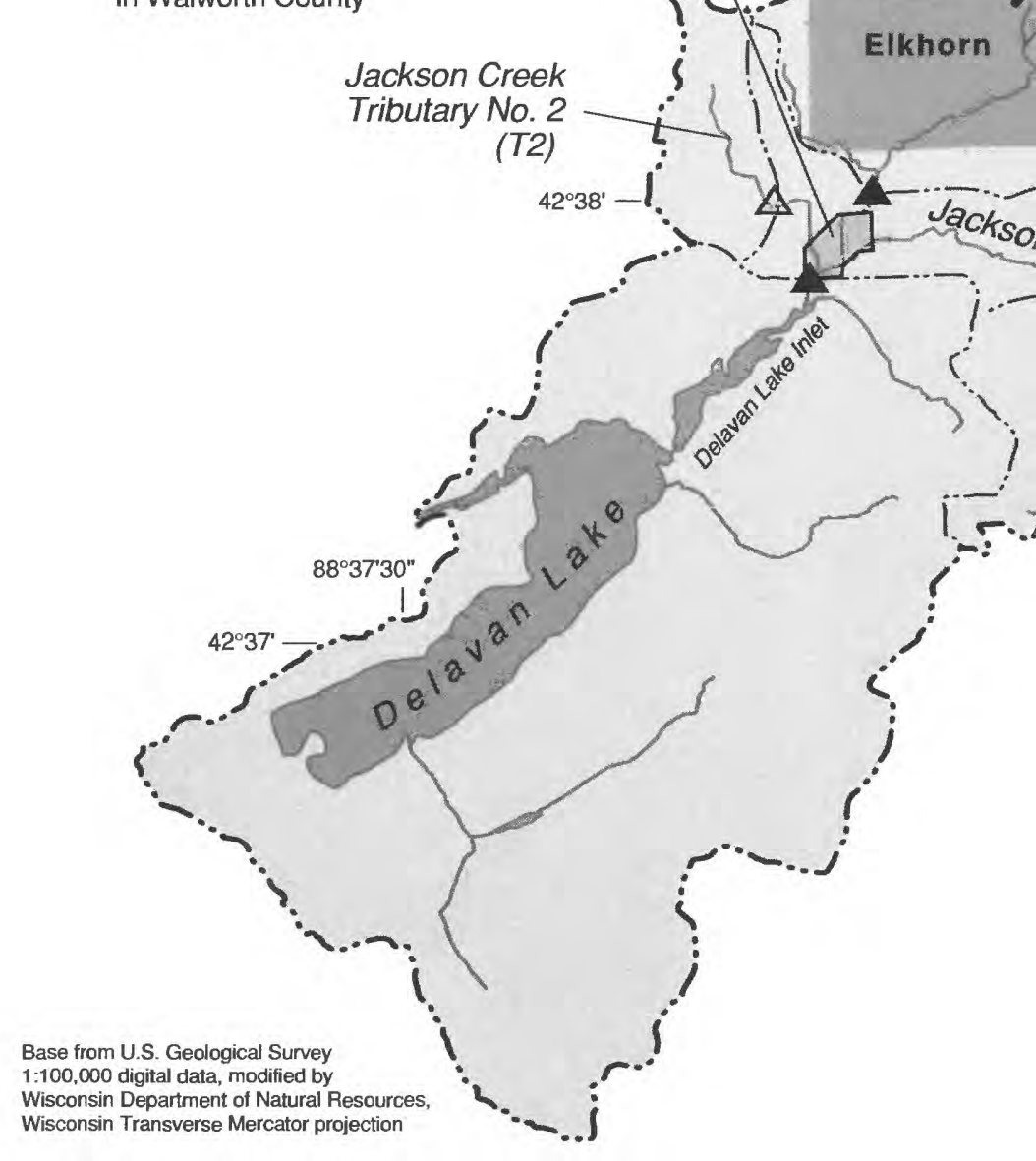




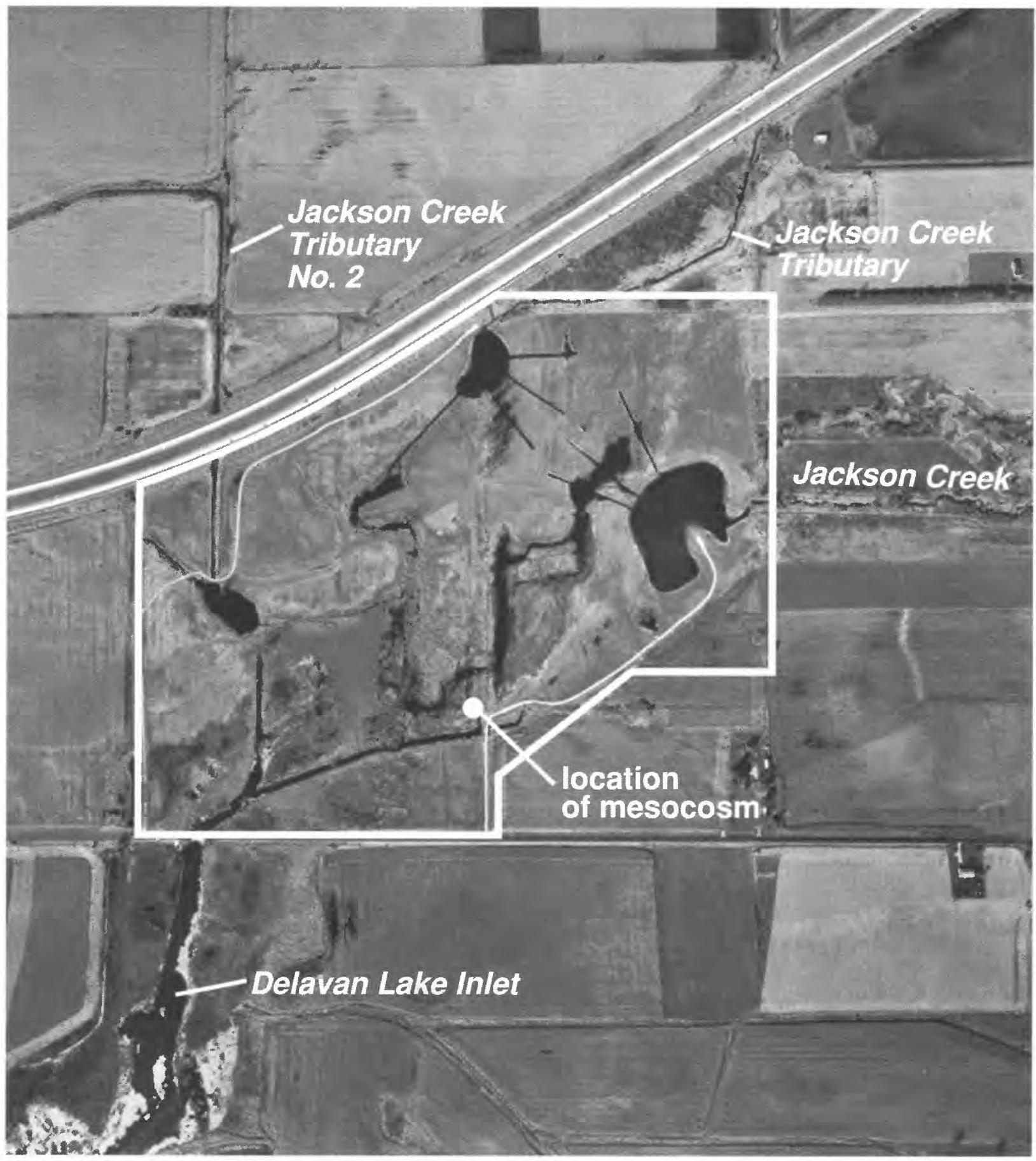

Figure 2. Aerial view of Jackson Creek Wetland showing inflowing and outflowing streams and location of mesocosm (photograph suppiied by Rust Environmental and Infrastructure, Inc., Milwaukee, Wis.). 


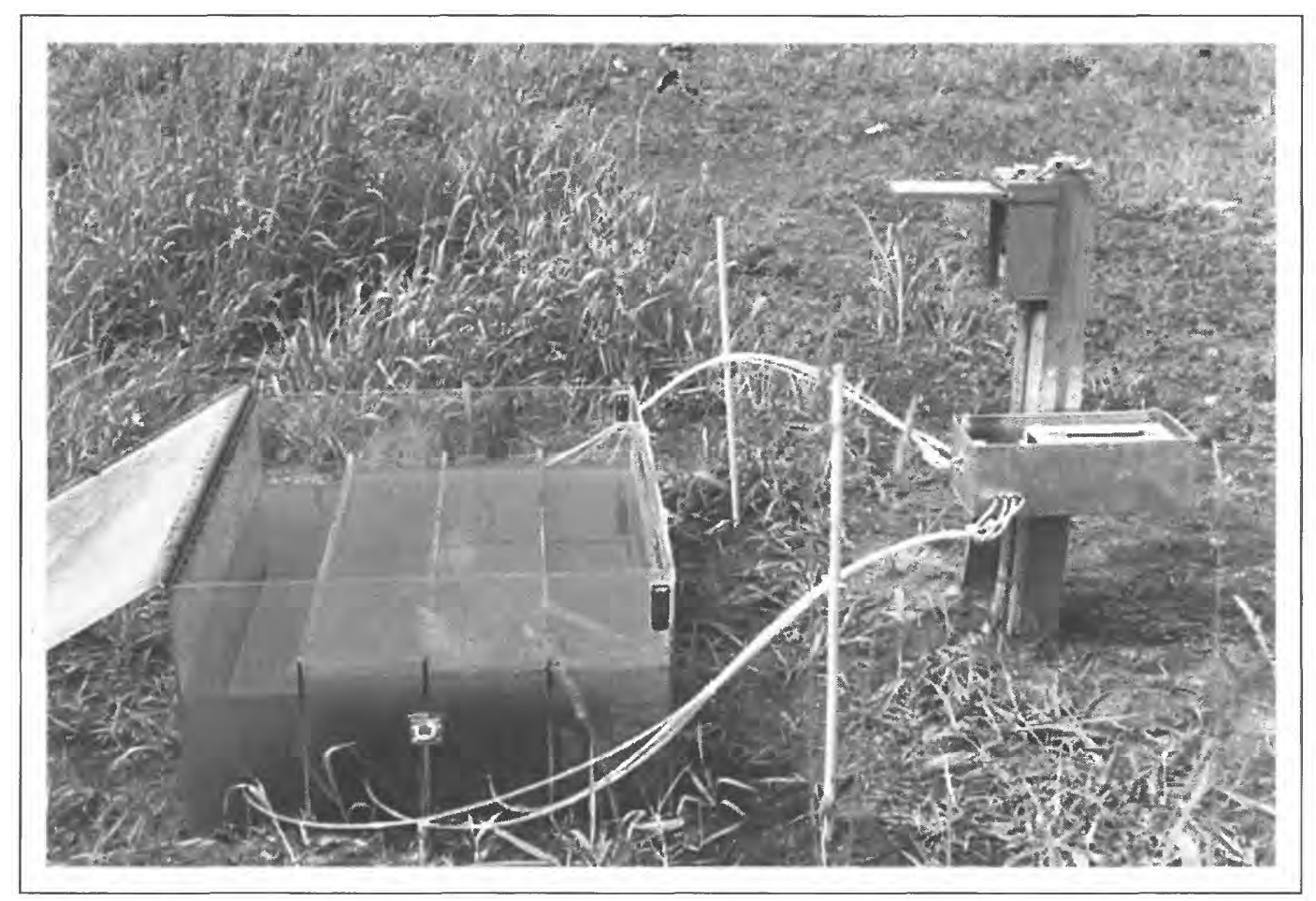

Figure 3. Mesocosm in place in Jackson Creek Wetland.

\section{EXPERIMENTAL DESIGN AND METHODS OF DATA COLLECTION}

\section{Mesocosm Design}

The mesocosm used for these experiments consisted of an aquarium-type enclosure, constructed of transparent, high-density acrylic plastic and subdivided into four flow-through cells (fig. 3, and cover photo). Each cell was $1.23 \mathrm{~m}$ long and $0.23 \mathrm{~m}$ wide and had a capacity volume of approximately $150 \mathrm{~L}$. The entire enclosure was covered with a transparent acrylic lid, hinged on one side for access to all cells. Ventilation plates were installed on the front and back faces of the tank near the top to provide exposure to the atmosphere.

Inflow and outflow ports were located approximately $30 \mathrm{~cm}$ above the tank base at opposite ends of each cell. Silicone tubing (64-mm ID) connected the inflow and outflow ports of each cell with individual cartridge pump modules driven by a multiflex-drive pump. This arrangement provided a controlled, circulating flow system for each cell. The pump was set to maintain a flow rate of approximately $50 \mathrm{~L} / \mathrm{h} / \mathrm{m}^{2}$. By comparison, the average discharge of Jackson Creek at the wetland outlet $\left(0.34 \mathrm{~m}^{3} / \mathrm{s}\right)$ translates to an area-normalized flow rate of $3.2 \mathrm{~L} / \mathrm{h} / \mathrm{m}^{2}$. However, this average represents an extremely wide range of flows in the nat- ural system, including many sites where flows are comparable to the controlled flow rate of the experiments.

\section{Mesocosm Experiments}

An initial test of the hydraulic flow properties of the mesocosm was conducted in the laboratory prior to the experiments. Each cell was filled with tap water to a depth of $45 \mathrm{~cm}$. A dye was introduced by injection into the inflow lines, and the distribution of the dye was monitored over time, with photographic record of its dispersal. At a flow rate of $50 \mathrm{~L} / \mathrm{h} / \mathrm{m}^{2}$, the dye was dispersed uniformly throughout the bottom half of the enclosed water within one hour, and throughout the system in less than 24 hours.

Three experiments were conducted in the mesocosm between February and October, 1993. For all experiments, the cells were filled with water to a depth of $35-45 \mathrm{~cm}$. The water in all cells was from a channel within Jackson Creek wetland, collected just prior to beginning the experiments. In each experiment, three of the four cells also contained sediments collected from near the mouths of the three feeder streams of Jackson Creek wetland. The sediments consisted of composites of grab samples, collected just prior to beginning the experiments by dredging or scooping from surficial deposits. Approximately $0.02 \mathrm{~m}^{3}$ of sed- 
Table 1. Composite daily means (medians of $\mathrm{pH}$ ) and ranges of water properties in mesocosm cells and in Jackson Creek Wetland (two locations) during diurnal monitoring, June and October, 1993

\begin{tabular}{lccc}
\hline & $\begin{array}{c}\text { Mesocosm } \\
\text { Cells }\end{array}$ & $\begin{array}{c}\text { Channel near } \\
\text { Mesocosm }\end{array}$ & $\begin{array}{c}\text { Wetland } \\
\text { Outlet }\end{array}$ \\
\hline pH & June 24,1993 & & \\
Temperature (degrees Celsius) & 8.6 & 8.2 & \\
& $8.1-9.2$ & $8.1-8.3$ & \\
Dissolved oxygen (milligrams per liter) & 28.1 & 24.0 & \\
& $25.0-31.7$ & $19.8-28.2$ & \\
Specific conductance (microsiemens per cm) & 15.2 & 9.1 & \\
& $10.4-22.9$ & $6.9-11.1$ & 8.8 \\
& 550 & 703 & $8.7-8.9$ \\
& $491-595$ & $652-730$ & 11.0 \\
pH & October 5, 1993 & & \\
Temperature (degrees Celsius) & 8.4 & 8.5 & \\
& $8.0-8.9$ & 14.3 & 3.7 \\
Dissolved oxygen (milligrams per Liter) & 14.5 & $12.6-16.8$ & $2.9-4.3$ \\
\hline
\end{tabular}

iment in each cell produced a sediment layer $6-7 \mathrm{~cm}$ thick. The fourth cell, containing water only, served as a control. Chemical characteristics of the wetland and mesocosm water are given in table 1 .

After the mesocosm cells were filled according to the specifications of each experiment, a 24-hour settling period was allowed prior to pumping. Thereafter, water samples were collected periodically for phosphorus analysis. The sampling was done from the outflow line by disconnecting the line temporarily from the pump module and allowing the water to flow directly into a sample collection bottle. Sampling was done in triplicate in experiments 1 and 2 to determine the sample reproducibility.

Experiment 1 was conducted in the laboratory, February 1-March 29. Although located indoors, the mesocosm was exposed to the natural light cycle because of its placement adjacent to a large window. Air temperature of $20-22^{\circ} \mathrm{C}$ was maintained in the ventilated room throughout the experiment.

Each of the three experimental cells in Experiment 1 contained sediments from one of the three feeder streams of Jackson Creek wetland; hence, each stream was represented by a different cell. Sediment samples from the same three locations were also used for analysis of total and extractable phosphorus, inorganic and organic carbon, and grain-size distribution. The control cell contained no sediments. Water sampling for total phosphorus (TP) analysis was done at the end of four intervals during the experiment. At the beginning of the experiment, and at periodic intervals, the outflow water in each cell was monitored for dissolved oxygen content (measured by the Winkler titration method) and TP concentration.

For the last two experiments, the mesocosm was placed in the Jackson Creek wetland. Its location (fig. 2) was within a few meters of a shallow channel whose water surface was approximately at the same elevation as the base of the tank. The soils at this location were nearly always saturated but rarely flooded. The tank was placed in a depression created by removal of soil and vegetation to an approximate depth of $20 \mathrm{~cm}$. After placement of the tank, soil was refilled around the tank base. The pumping equipment was housed in a watertight metal box, mounted adjacent to the mesocosm.

In experiment 2 , each of the three experimental cells again contained sediments collected from one of the three feeder streams of Jackson Creek wetland. The duration of the experiment was 22 days (June 17-July 8). Water sampling for TP analysis was done five times during this period and was accompanied by measurements of water temperature, $\mathrm{pH}$, specific conductance, and dissolved oxygen (DO) in each cell, made with a multiparameter water-monitoring instrument. A diurnal study was conducted on June 24 , during which triplicate water samples for phosphorus analysis were collected three times (morning, midday, and dusk) and 
water-quality monitoring was done five times from 7:00 a.m. until 6:00 p.m.

In experiment 3 , the sediments contained in all three experimental cells were collected from the same location - the mouth of Jackson Creek. All experimental cells contained sediments and water, as in the previous experiment. However, two of the cells had additional treatment. One was biologically inhibited by addition of a solution of copper sulfate sufficient to bring the final concentration to $10 \mathrm{mg} \mathrm{Cu} / \mathrm{L}$. In another cell, specimens of emergent vegetation from the wetland, primarily equisetum (Equisetum sp.) and reed canary grass (Phalaris arundinaceae L.), were planted in the sediments.

Experiment 3 was conducted for a period of 40 days (September 8-October 17). Water samples for TP and soluble reactive phosphorus (SRP) analysis were collected at day 0 and 12 additional times during this period. As in experiment 2, water sampling was accompanied by measurements of water temperature, $\mathrm{pH}$, and dissolved oxygen in each cell. On October 5, a diurnal study was completed, with a design like that of June 24 except that water-quality monitoring was done hourly.

Henceforth, the control and the copper-treated cells in these experiments are termed "abiotic" systems, whereas the cells containing sediments or sediments plus vegetation are considered as "live" or "biologically-rich" systems. Biological activity was not truly absent in the control cells, or even in the copper-treated cell; however, lacking the organic richness associated with introduced sediments and macrophytes, the biological activity in these cells was comparatively restricted.

\section{Analytical methods}

Samples to be analyzed for soluble reactive phosphorus were filtered through a 0.45 -m filter and chilled. Analysis was by the molybdate/ascorbic acid colorimetric procedure (reaction of orthophosphate with ammonium molybdate and antimony potassium tartrate, producing an antimony-phospho-molybdate complex which is reduced to the colored complex by ascorbic acid). Colorimetric detection on an autoanalyzer was completed within 24 hours after complexation. For total phosphorus analysis, samples were preserved immediately with $12.5 \% \mathrm{H}_{2} \mathrm{SO}_{4}$ and chilled. All phosphorus was converted to orthophosphate by digestion in an autoclave with ammonium persulfate and sulfuric acid. The orthophosphate was then analyzed by the same colorimetric procedure as that used for SRP. The analytical methods yield SRP and TP values corresponding to Storet codes 00671 and 00665 , respectively, and are described in detail in the Standard Methods handbook (Clesceri and others, 1989).

Analysis of total phosphorus in sediment was conducted as described above, following 24-h digestion with $0.5 \mathrm{~N} \mathrm{HCI}$ (Hieltjes and Lijklema, 1980). Extractable (weakly-bound) phosphorus was also determined, using the same analytical procedure on samples that were treated with $0.1 \mathrm{~N} \mathrm{NaOH}$ to solubilized $\mathrm{P}$ associated primarily with $\mathrm{Fe}$ and $\mathrm{Al}$. Triplicate measurements of both the TP and extractable P fractions were made on all sediment types.

Total carbon (inorganic plus organic) in bottom sediment was determined by measurement of carbon dioxide evolved by thermal conductivity following catalytic oxidation of the sample in an induction furnace (Wershaw and others, 1987). The inorganic fraction was determined by treating the sample with aqueous hydrochloric acid in a modified Van Slyke apparatus and heating to release carbon dioxide, which was measured manometrically. The concentration of organic carbon in the sediment was then computed by difference.

\section{Measurement of water flows and calculation of phosphorus loads}

Details of the study of water flow and phosphorus loads in the wetland were described by Goddard and Elder (1997). Water flow (discharge) was measured continuously at gaging stations located upstream of the Jackson Creek wetland at the Jackson Creek and Jackson Creek Tributary (T1) sites, and at the wetland outflow weir (fig. 1). Inflow through Jackson Creek Tributary 2 (T2) was also measured periodically. Stream samples (composites of samples collected in equal-width increments across the channel) were collected at least monthly for phosphorus analysis. For each sampling interval, the phosphorus load into and out of the wetland was computed as the sum of products of integrated concentrations and corresponding streamflows (Porterfield, 1972). 


\section{RESULTS OF MESOCOSM EXPERIMENTS}

\section{Retention of Phosphorus in Mesocosm Cells}

Results from experiments 1 and 2, comparing sediment/water systems with controls (water alone), indicated that phosphorus retention was generally diminished in the cells containing sediments (fig. 4). At each observation following the initial day, high TP concentrations, relative to those in control cells, characterized the outflows of one or more of the sedimentcontaining cells. Such concentration differences between experimental and control cells were observed throughout the experiments, indicating that this effect was more than a sudden pulse created by the initial mixing of sediments with water. The higher concentrations reached in experiment 2 were probably due to the higher water temperatures and more rapid nutrient cycling associated with biological uptake and release.

Among the three sediment types, appreciable differences were found in their effects on phosphorus retention in the mesocosm cells. Water overlying tributary 1 sediments contained elevated TP concentrations throughout experiment 1 and through the first 11 days in experiment 2. In water overlying the Jackson Creek sediments, TP concentrations were indistinguishable from those of the control cell in experiment 1 , but increased markedly during the first 11 days in experiment 2, and remained high for the remainder of the experiment. On most sampling days in both experiments, TP concentrations in the T2 cell were comparable to those of the control cell.

Analyses of TOC and phosphorus contents of the three sediment types (table 2) showed consistently elevated concentrations of TOC, total $\mathrm{P}$, and extractable $\mathrm{P}$ in tributary 1 sediment. These constituents were at somewhat lower concentrations in the other two sediment types - from Jackson Creek and T2. TOC nearly doubled, from 11 to $21 \mathrm{~g} / \mathrm{kg}$, in Jackson Creek sediment between experiment 1 and 2, while decreasing from 23 to $17 \mathrm{~g} / \mathrm{kg}$ in T2 sediment. Jackson Creek sediment had lower TP, but higher extractable P concentrations, than T2 sediment.

In experiment 3 , effects of rooted vegetation on phosphorus retention were superimposed on tests of sediment effects. In addition, changes in SRP, as well as TP, were monitored. The results, shown in fig. 5 , again demonstrated diminished $\mathrm{P}$ retention in the sediment-containing systems relative to the control system.

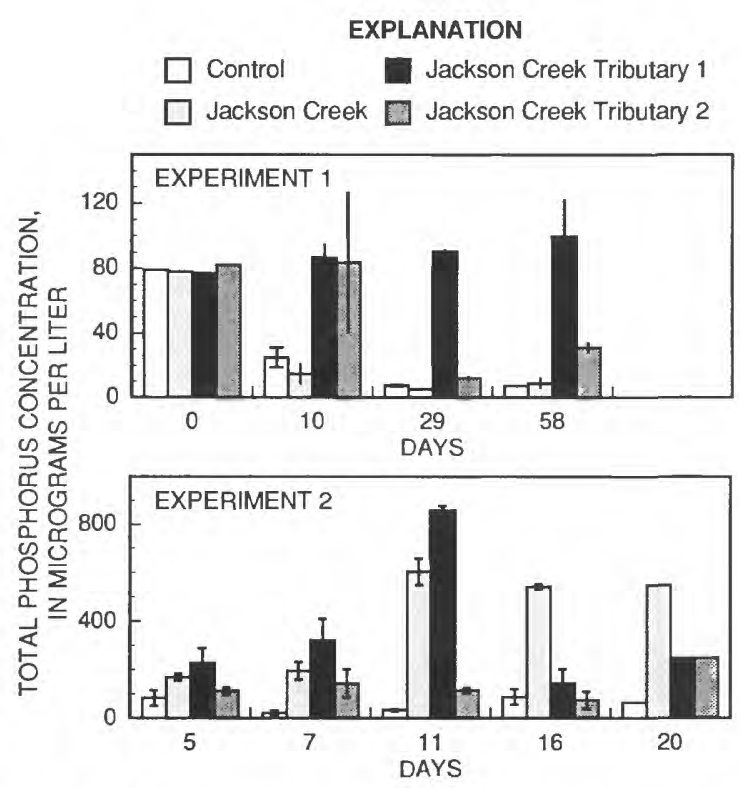

Figure 4. Comparison of total phosphorus concentrations in control cells vs. cells containing sediments and water, experiments 1 and 2 . Each sediment cell contained sediments from a different channel as indicated. Error bars show one standard deviation range, based on triplicate samples.

This was especially true in the sediment cell, whose phosphorus concentrations typically exceeded those of the control by factors of 3-5 (TP) and 8-12 (SRP). In the vegetated cell, TP concentrations were about the same as those of the control during the first 23 days but increased substantially thereafter. TP concentrations in the control and copper-treated cells declined from initial levels of $220-240 \mu \mathrm{g} / \mathrm{L}$ to less than $50 \mu \mathrm{g} / \mathrm{L}$. Similar declines in SRP occurred from $30-40 \mu \mathrm{g} / \mathrm{L}$ to less than $10 \mu \mathrm{g} / \mathrm{L}$.

Possible sources of phosphorus concentration variability included not only contents of the cells, but also time. This is due to the fact that samples were collected at different intervals. In the absence of treatment replications, this additional source of variability prevents statistical testing of the observed differences in experimental results. However, the reproducibility, through time and among sample replicates, of the phosphorus concentration differences among treatments is evidence of true differences among cells, as observed.

\section{Diurnal Variation in Mesocosm Cells and Surrounding Wetland}

The diurnal series of measurements on June 24 and October 5, 1993 showed that the natural system and the biologically active cells (containing sediments or sediments plus vegetation) followed a pattern of 
Table 2. Aqueous total phosphorus $(P)$ concentrations in mesocosm cells (excluding day 0 ) and initial concentrations of organic carbon (TOC), total phosphorus, and $\mathrm{NaOH}$-extractable phosphorus in sediments of corresponding cells

$[\mu \mathrm{g} / \mathrm{L}$, micrometers per liter; $\mathrm{g} / \mathrm{kg}$, grams per kilogram; $\mathrm{mg} / \mathrm{kg}$, milligrams per kilogram. All values are means of $\mathrm{n}$ measurements (including each replicate measurement); standard deviations in parentheses. Control cell contained no sediments.]

\begin{tabular}{crrrr}
\hline & Trib. 1 & Jackson Cr. & Trib. 2 & Control \\
\hline Total P in water $(\mu \mathrm{g} / \mathrm{L})$ & & & & \\
\hline Experiment I & 92 & 9 & 42 & 13 \\
$(\mathrm{n}=9)$ & $(13)$ & $(5)$ & $(39)$ & $(9)$ \\
Experiment 2 & 378 & 390 & 122 & 57 \\
$(\mathrm{n}=13)$ & $(285)$ & $(204)$ & $(54)$ & $(35)$ \\
\hline TOC in sediments $(\mathrm{g} / \mathrm{kg})$ & & & & \\
\hline TOC, Experiment 1 & 55 & 11 & 23 & \\
$(\mathrm{n}=2)$ & $(2)$ & $(1)$ & $(1)$ & \\
TOC, Experiment 2 & 31 & 21 & 17 & \\
$(\mathrm{n}=3)$ & $(2)$ & $(3)$ & $(1)$ & \\
\hline Phosphorus in sediments $(\mathrm{mg} / \mathrm{kg})$ & & & & \\
\hline Total P & 1400 & 960 & 1100 & \\
$(\mathrm{n}=3)$ & $(173)$ & $(52)$ & $(0)$ & \\
Extractable P & 383 & 146 & 87 & \\
$(\mathrm{n}=3)$ & $(47)$ & $(14)$ & $(4)$ & \\
Percent extractable & 27 & 15 & & \\
\hline
\end{tabular}

diurnal cycling of dissolved oxygen that is characteristic of photosynthetic effect (early morning minimum and afternoon maximum). In contrast, almost no DO cycle was observed in the control cells or the coppertreated cell. All mesocosm cells, and the ambient Jackson Creek water, were very similar to each other with respect to diurnal variability and ranges of the other measured parameters (temperature, $\mathrm{pH}$, and specific conductance; table 1).

Water analyses during the two diurnal series showed no evidence of a diurnal pattern of phosphorus retention or release. The TP concentration variability in these series was no greater than among triplicate samples collected in immediate sequence, and no consis- tent pattern of increasing or decreasing phosphorus concentrations with time occurred.

\section{PHOSPHORUS LOADS IN JACKSON CREEK WETLAND}

Data from phosphorus loading and budget estimates, based on measurements of water flow and phosphorus concentrations at the three surface-water inflows and the outlet of the Jackson Creek wetland, are shown in table 3. For all three years, and for both total $\mathrm{P}$ and SRP, the annual data showed inflows exceeding outflows, resulting in negative percent

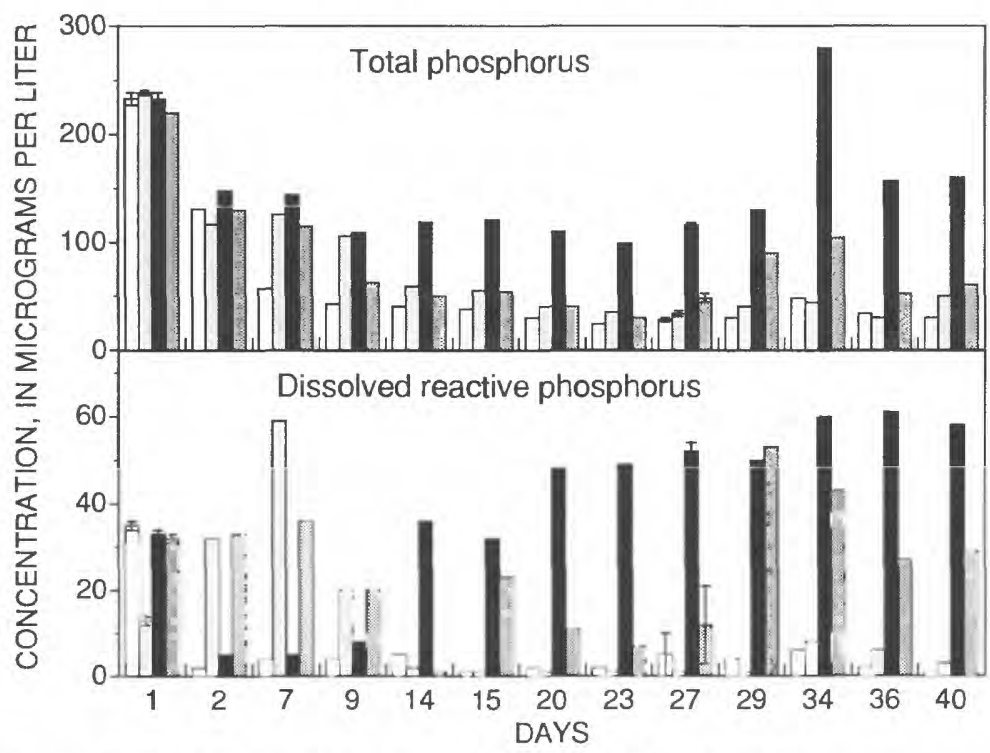

\section{EXPLANATION}

Cell Contents

$\square$ Control

$\square$ Sediments and copper

- Sediments

중 Vegetated

Figure 5. Total and soluble phosphorus in outflows from four mesocosm cells; experiment 3 . Values for days 1 and 27 are means of triplicates; error bars show one standard deviation range. 
Table 3. Inflow and outflow phosphorus loads for Jackson Creek Wetland, February 1993-September 1995 [P. phosphorus; SRP, soluble reactive phosphorus; kg, kilogram. Data grouped by water year (October-September).]

\begin{tabular}{|c|c|c|c|c|c|c|c|}
\hline & Water Year & $\begin{array}{c}\text { Inflow } \\
(\mathrm{kg})\end{array}$ & $\begin{array}{l}\text { Outflow } \\
\text { (kg) }\end{array}$ & $\begin{array}{l}\text { Percent } \\
\text { change }\end{array}$ & $\begin{array}{l}\text { Months of } \\
\text { major } \\
\text { inflow }\end{array}$ & $\begin{array}{l}\text { Months of } \\
\text { major } \\
\text { retention }\end{array}$ & $\begin{array}{l}\text { Months of } \\
\text { major } \\
\text { release }^{3}\end{array}$ \\
\hline \multicolumn{8}{|l|}{ Total P } \\
\hline & $1993^{4}$ & 5044 & 4577 & -9 & $4,3,6,7$ & $6,3,7,5$ & 4 \\
\hline & 1994 & 2436 & 1480 & -39 & 2 & 2,4 & $7,8,9,5$ \\
\hline & 1995 & 1227 & 1077 & -12 & 8,4 & 4,8 & 6,9 \\
\hline \multicolumn{8}{|l|}{ SRP } \\
\hline & $1993^{4}$ & 2759 & 2494 & -10 & $3,4,6,7$ & $6,7,5,4$ & 3,8 \\
\hline & 1994 & 902 & 793 & -12 & 2,3 & 2 & $7,8,9$ \\
\hline & 1995 & 478 & 420 & -12 & 8,4 & $4,1,5$ & 8 \\
\hline
\end{tabular}

changes, and indicating net uptake of phosphorus during flow through the system. However, the monthly data (last three columns of table 3 ), showed considerable variation over a shorter time scale, including, in some months, phosphorus releases that exceeded uptake. The monthly data showed quite consistently that: (1) the greatest net retention usually corresponded to periods of high flow, and (2) most periods of net release occurred during the low-flow summer months.

Some of the year to-year and month-to-month variability may be attributable to climate and its effect on hydrologic conditions. The area received unusually high rainfall in 1993 and phosphorus inflows were more than twice the normal amounts, as seen by comparison to the following two years (table 3 ). During the drier conditions of water year 1994, the net annual TP retention was much higher than in the other two years.

\section{FACTORS AFFECTING PHOSPHORUS RETENTION AND RELEASE}

\section{Biological Cycles}

The results of the mesocosm experiments at the Jackson Creek wetland repeatedly demonstrated reduced $\mathrm{P}$ retention with increased biological activity and/or presence of sediments in the enclosed systems. Although this observation seems to be in conflict with the conventional concept of the wetland as a nutrient trap or filter, the conflict is more apparent than factual. The retention and release functions of the wetland are not mutually exclusive. They are more appropriately considered as alternating outcomes of a great variety of biogeochemical interactions and processes in the system.

What mechanisms of phosphorus cycling might explain reduced phosphorus retention in the presence of sediments or biologically activity? Biological processes, whether associated with macrophytes or with algae and microbiota in the sediments, involve not only uptake of bioavailable phosphorus, but also phosphorus mineralization and release that follows incorporation and metabolic utilization of the nutrient. Mobilization of phosphorus buried in bottom sediments may also be stimulated by burrowing activity of benthic organisms (Everest and Davis, 1979). If phosphorus is added to a system where it is the limiting nutrient, it will stimulate rapid growth (Santiago and Thomas, 1992), favoring, at least temporarily, an autotrophic system with a high productivity (Welch, 1992). Later, as the biomass increases, growth approaches the limits imposed by nutrient availability. This progression leads to decreased phosphorus uptake and increased phosphorus release associated with excretion and senescence of the increased biomass (Chale, 1989; Welch, 1992; Dierberg, 1993; Jannson, 1993). Hence, the balance between uptake and release shifts in accordance with the production:respiration ratio. In terms of the phosphorus cycle, the biota thus 
serve not simply as consumers of the nutrient, but as capacitors - capable of incorporation and storage during periods of growth, and release at other times.

\section{Abiotic Processes}

Abiotic mechanisms of phosphorus retention and release involve chemical precipitation/dissolution and adsorption/desorption processes (Wetzel, 1983; Griffloen, 1994). Because these processes may proceed whether or not biota are present, one should be able to observe their effects in abiotic systems, unmasked by biologically mediated transport processes. The inclusion of the control and copper-treated systems in the experiments provided opportunity for comparison of relatively abiotic systems to systems that contained sediment-associated biota and attached vegetation.

The chemical precipitation and sorption processes that reduce the mobility of phosphorus in the abiotic systems might be reversed in the event of critical chemical changes in the medium, such as major $\mathrm{pH}$ shifts or transition from oxic to anoxic conditions (Detenbeck and Brezonik, 1991). As indicated by the results of diurnal measurements however, no such changes occurred in the mesocosm cells; therefore, the phase transfers for phosphorus would be primarily unidirectional toward the particulate forms. In contrast, the stability and mobility of biologically incorporated phosphorus in the sediment-containing systems would be subject to change associated with physiological and ecological cycles in the mesocosm cells. As a result, the experiments showed greater tendencies for phosphorus-concentration fluctuations in the biologically rich systems than in the abiotic systems (figs. 4 and 5).

\section{Organic carbon}

If phosphorus release from sediments is a function of metabolic processes, and the rates of such processes are correlated with biomass in the sediments, then a relation between dissolved phosphorus concentrations and total organic carbon (TOC) in the sediments should exist. The data of table 2 provide some evidence of such a relation. Water overlying the TOCrich $\mathrm{T} 1$ sediments consistently contained high TP concentrations. However, the relation is much less clear for the other two sediments. Their TOC contents changed substantially between Experiments 1 and 2; some, but not complete, correspondence to these changes were observed in TP concentrations in the overlying water.

Enhanced phosphorus transfer from sedimentary to aqueous phase in systems with TOC-enriched sediments may be explained not only by the likely association with the microbiological community, but also by a number of chemical processes (Wetzel, 1983), two of which seem most plausible in this case. The first is that high TOC content increases the oxygen demand and favors reducing conditions that mobilize phosphorus associated with metal precipitates. A second possibility applies to oxic conditions; the organic enrichment increases phosphorus mobilization by favoring the formation of sestonic and colloidal organic phosphorus.

\section{Sedimentary phosphorus}

Phosphorus speciation has been shown to be important in many wetland systems (Elder, 1985; Richardson, 1985, 1988; Masscheleyn and others, 1992). Particulate phosphorus may contain large proportions of bioavailable and mobile forms (Peters, 1981; Mayer and others, 1991), and these proportions can be estimated based on analytical determinations of readily extractable fractions (Hieltjes and Lijklema, 1980).

The rate of phosphorus transfer from solid to aqueous phase would be expected to increase in proportion to the extent to which the sedimentary phosphorus is mobile or loosely bound. The determinations of phosphorus speciation in the Jackson Creek tributary sediments (table 2) at least partially confirmed this expectation, showing total phosphorus enrichment in T1 sediments, the same sediments that most consistently produced high phosphorus concentrations in overlying water. Perhaps more importantly, $27 \%$ of the phosphorus in those sediments was extractable. Sediments of the other two tributaries, with lower total $\mathrm{P}$ concentrations and smaller extractable $\mathrm{P}$ fractions, released diminished and more variable amounts of dissolved phosphorus to overlying water.

\section{Sediment particle size}

Sediment particle size is another factor that is known to be a key control on adsorption of dissolved constituents (Horowitz, 1991). Particle-size analyses on the sediments from Jackson Creek revealed very few differences in their particle-size distributions; all sediments were sandy/loamy mixtures. Hence, the sed- 
iment types could not be distinguished by particle size, and the data did not provide a basis for conclusions about possible relations between particle size and uptake or mobility of phosphorus in the system.

\section{ANNUAL VS. SHORT-TERM PHOSPHORUS RETENTION}

The fact that net annual phosphorus retention was observed in each of three years in the Jackson Creek wetland (table 3 ) suggests that the wetland functions as an effective trap for phosphorus. However, the annual mass balances do not provide complete information about the import/export dynamics. The monthto-month variability (last two columns of the table 3 ) was such that major net retention of phosphorus occurred in some months and major net release occurred in others.

Net retention on an annual time scale occurs primarily because the months of high retention tend to coincide with months of high inflow, usually in the spring. This relation is in conflict with the expectation that high flows would reduce phosphorus removal because of reduced contact between water and sediments (Heikkinen and others, 1995). In this system, it might be explained by seasonal variability in the role of sediments in phosphorus transport: much phosphorus associated with sediments in winter and spring is removed with sediments settling in the wetland; while in summer, a greater fraction of the phosphorus is dissolved and the settling factor becomes less important. The net phosphorus releases during the summer, although small because of the low flow, represented a significant potential impact because of their timing during the summer when vegetative growth is most active and algal blooms in Delavan Lake are most likely.

The high annual total phosphorus retention in water year 1994, relative to 1993 which had much greater rainfall, might suggest that lower flows favor increased retention. Again, further examination of the data disproves this oversimplification. Monthly data (not shown in the table) showed that nearly all of the phosphorus retention of 1994 happened in the month of February; by contrast, small but consistent $P$ release was observed in all months from May through October. Furthermore, in 1995, which had even less rainfall than 1994, TP retention returned to a level similar to that of 1993.

Another factor that could account for some of the variability in nutrient retention and release dynamics is community structure evolution during the early successional stages of the expanded wetland. In 1993, the Jackson Creek wetland was in its first year of development after restoration, and the communities and interspecies associations were not yet firmly established. As the system proceeds through succession during the following years and decades, much of its structure and its behavior, including the fluctuation between phosphorus uptake and release, is subject to change. Similar changes with time have been observed in other wetland systems (Nichols, 1983; Richardson, 1985; Richardson and Marshall, 1986). In particular, high initial rates of phosphorus removal by freshwater wetlands are likely to be followed by large phosphorus exports within a few years (Richardson, 1985).

The experimental results and field data from this study support the concept of wetlands as nutrient reservoirs and transformers, rather than simply as sources or sinks (Richardson, 1985, 1988; Elder, 1985, 1988; Gehrels and Mulamoottil, 1989). Because of the complexity and variability of biogeochemical cycling in wetlands, nutrient retention and release alternate in predominance and are both important functions of the system. Awareness of this concept may assist environmental managers to avoid placing unrealistic expectations for filtering capacity of natural or constructed wetlands.

\section{CONCLUSIONS}

The mesocosm experiments of this study generally indicated that phosphorus transport in the aqueous phase was enhanced, not inhibited, by the presence of sediments and vegetation from the natural wetland. The mass balance analysis for the wetland as a whole indicated that the system was a net importer for phosphorus on an annual time scale, but that periodic episodes of export can occur at critical times during the growing season. These results do not conflict with the general concept of nutrient retention in a wetland; rather they demonstrate the capacity of the system to function not only as a nutrient trap, but also, periodically, as a facilitator of nutrient transformation and transport.

The use of mesocosms as a tool for study of nutrient retention and mobilization in the natural system offers a small-scale view not readily available by whole-system analysis. It is most effective, however, when used in combination with nutrient-budget studies 
of the ecosystem as a whole, thus providing a multiscale perspective.

\section{REFERENCES CITED}

Boyt, F.L., Bayley, S.E., and Zoltek, J., Jr., 1977, Removal of nutrients from treated municipal wastewater by wetland development: Journal of Water Pollution Control Federation, v. 49, p. 789-799.

Brinson, M.M., Bradshaw, H.D., and Kane, E.S., 1984, Nutrient assimilative capacity of an alluvial floodplain swamp: Journal of Applied Ecology, v. 21, p. 10411057.

Brown, R.G., 1985, Effects of an urban wetland on sediment and nutrient loads in runoff: Wetlands, v. 4, p. 147-158.

Chale, F.M.M., 1989, Nutrient release from swamp water, Cyperus papurus L. organs, and swamp sediments: Hydrological Bulletin, v. 23, no. 2, p. 195-199.

Clesceri, L.S., Greenberg, A.E., and Trussell, R.R., (eds.). 1989. Standard Methods for the Examination of Water and Wastewater, 17th Edition (17 ed.). American Public Health Association, Washington, D.C.

Cooke, J.G., 1992, Phosphorus removal processes in a wetland after a decade of receiving a sewage effluent: Journal of Environmental Quality, v. 21, p. 733-739.

Detenbeck, N.E., and Brezonik, P.L., 1991, Phosphorus sorption by sediments from a soft-water seepage lake. 2. Effects of $\mathrm{pH}$ and sediment composition: Environmental Science and Technology, v. 25 , no. 3, p. 403409.

Dierberg, F.E., 1993, Decomposition of desiccated submersed aquatic vegetation and bioavailability of released phosphorus: Lake and Reservoir Management, v. 8, no. 1, p. 31-36.

Elder, J.F., 1985, Nitrogen and phosphorus speciation and flux in a large Florida river wetland system: Water Resources Research, v. 21, no. 5, p. 724-732.

Elder, J.F., 1988, Factors affecting wetland retention of nutrients, metals, and organic materials. p. 178-184. in: J.A. Kusler and G. Brooks (eds.), Wetland Hydrology, Chicago, IL, Association of State Wetland Managers, Inc., Berne, N.Y., U.S.A.

Elder, J.F., and Goddard, G.L., 1996, Sediments and nutrient trapping efficiency of a constructed wetland near Delavan Lake, Wisconsin, 1993-95: U.S. Geological Survey Fact Sheet FS-232-96, 4 p.

Everest, J.W., and Davis, D.E., 1979, Studies of phosphorus movement using salt marsh microecosystems: Journal of Environmental Quality, v. 8, no. 4, p. 465-468.

Field, S.J., and Duerk, M.D., 1988, Hydrology and water quality of Delavan Lake in southeastern Wisconsin: U.S. Geological Survey Water-Resources Investigations Report 87-4168, 61 p.
Gale, P.M., Reddy, K.R., and Traetz, D.A., 1994, Phosphorus retention by wetland soils used for treated wastewater disposal: Journal of Environmental Quality, v. 23, p. 370-377.

Gehrels, J., and Mulamoottil, G., 1989, The transformation and export of phosphorus from wetlands: Hydrological Processes, v. 3, p. 365-370.

Goddard, G.L., and Elder, J.F. 1997, Retention of sediments and nutrients in Jackson Creek Wetland near Delavan Lake, Wisconsin, 1993-95: U.S. Geological Survey Water-Resources Investigations Report 97-4014, 22 p.

Griffioen, J., 1994, Nitrogen and phosphorus losses from organic soils: Environmental Science and Technology, v. 28 , p. $675-681$.

Hammer, D.A., and Bastian, R.K., 1989, Wetlands ecosystems: natural water purifiers?: p. 5-19, chap. 12. in: D.A. Hammer (ed.) Constructed Wetlands for Wastewater Treatment, Municipal, Industrial and Agricultural, Lewis Publishers, Chelsea, MI.

Heikkinen, K., Ihme, R., and Hartikainen, H., 1995, Phosphate removal by peat from peat mining drainage water during overland flow wetland treatment: Journal of Environmental Quality, v. 24, no. 4, p. 597-602.

Hieltjes, A.H.M., and Lijklema, L., 1980, Fractionation of inorganic phosphates in calcareous sediments: Journal of Environmental Quality, v. 9, no. 3, p. 405-407.

Horowitz, A.J., 1991, Sediment-Trace Element Chemistry: Chelsea, MI, Lewis Publishers (2nd ed.), 136 p.

Jannson, M., 1993, Uptake, exchange, and excretion of orthophosphate in phosphate-starved Scenedesmus quadricauda and Pseudomonas K7: Limnology and Oceanography, v. 38, no. 6, p. 1162-1178.

Kadlec, R.H., 1989, Decomposition in wastewater wetlands: p. $459-468$, chap. 437 a. in: D.A. Hammer (ed.) Constructed Wetlands for Wastewater Treatment, Municipal, Industrial and Agricultural, Lewis Publishers, Chelsea, MI.

Kadlec, R.H., and Knight, R.L., 1996, Treatment Wetlands: Boca Raton, FL, Lewis 928 p.

Masscheleyn, P.H., Pardue, J.H., DeLaune, R.D., and Patrick, W.H., Jr., 1992, Phosphorus release and assimilatory capacity of two lower Mississippi Valley freshwater wetland soils: Water Resources Bulletin, v. 28, no. 4 , p. 763-773.

Mayer, T., Kuntz, K.W., and Moller, A., 1991, Total and bioavailable particulate phosphorus loads from the Niagara River in 1987 and 1988: Journal of Great Lakes Research, v. 17 , no. 4, p. 446-453.

Moshiri, G.A., (ed.) 1993. Constructed Wetlands for Water Quality Improvement. Lewis, Boca Raton, FL, 656 p.

National Research Council, 1995, Wetlands: characteristics and boundaries: Washington, D.C., National Academy Press $306 \mathrm{p}$. 
Nichols, D.S., 1983, Removal of nutrients from treated municipal wastewater by wetland development: Journal of Water Pollution Control Federation, v. 55, p. 495505.

Peters, R.H., 1981, Phosphorus availability in Lake Memphremagog and its tributaries: Limnology and Oceanography, v. 26, no. 6 , p. 1150-1161.

Porterfield, G., 1972, Computation of fluvial-sediment discharge: U.S. Geological Survey Techniques of WaterResources Investigations Book 3, Chap. C3, 66 p.

Puckett, L.J., Woodside, M.D., and Yanosky, T.M., 1993, Sinks for trace metals, nutrients, and sediments in wetlands of the Chickahominy river near Richmond, Virginia: Wetlands, v. 13, no. 2, p. 105-114.

Richardson, C.J., 1985, Mechanisms controlling phosphorus retention capacity in freshwater wetlands: Science, v. 228, no. 4706, p. 1424-1427.

Richardson, C.J., and Marshall, P.E., 1986, Processes controlling movement, storage, and export of phosphorus in a fen peatland: Ecological Monographs, v. 56, no. 4, p. 279-302.

Richardson, C.J., 1988, Freshwater wetlands: transformers, filters, or sinks?: Forem (Duke University), v. 11, no. 2, p. 3-9.

Robertson, D.M., Field, S.J., Elder, J.F., Goddard, G.L., and James, W.F., 1996, Phosphorus dynamics in Delavan Lake inlet, southeastern Wisconsin, 1994: U.S. Geological Survey Water-Resources Investigations Report 97 4014, 22 p.

Santiago, S., and Thomas, R.L., 1992, Phytoplankton utilization of phosphorus bound to suspended sediments from selected tributaries to Lake Geneva: Journal of Great Lakes Research, v. 18, no. 3, p. 372-389.

Van der Linden, M.J.H., 1989, Release of sedimentary nitrogen and phosphorus in polder ditches of a low-moor peat area: Hydrological Bulletin, v. 23, no. 2, p. 125134.

Watson, J.T., Reed, S.C., Kadlec, R.H., Knight, R.L., and Whitehouse, A.E., 1989, Performance expectations and loading rates for constructed wetlands: p. 319-351, chap. 327. in: D.A. Hammer (ed.) Constructed Wetlands for Wastewater Treatment, Municipal, Industrial and Agricultural, Lewis Publishers, Chelsea, MI.

Welch, E.B., 1992, Ecological Effects of Wastewater: London, Chapman and Hall (2nd ed.), $425 \mathrm{p}$.

Wershaw, R.L., Fishman, M.J., Grabbe, R.R., and Lowe, L.E., 1987, Methods for the determination of organic substances in water and fluvial sediments: U.S. Geological Survey Techniques of Water-Resources Investigations Book 5, Chap. A3, 80 p.

Wetzel, R.G., 1983, Limnology: Philadelphia, W.B. Saunders Co. (2nd ed.), 767 p.

Wisconsin Department of Natural Resources, 1989, Environmental impact statement on the Delavan Lake rehabilitation project, Walworth County, Wisconsin. p. 199. in: Wisconsin Department of Natural Resources, Bureau of Environmental Analysis and Review, Madison, WI. 